УДК 930(292.6)

DOI 10.31.65/2520-6966-2020-13i-99-121-132

\title{
Е. Кучменко
}

доктор історичних наук, професор кафедри всесвітньої історії та міжнародних відносин Ніжинського державного університету імені Миколи Гоголя ORCID ID 0000-0003-1311-4181, e-mail: kuchmeb@yahoo.com;

\section{Трансфрормації африканського суспільства в контексті взаємодії історико-культурних процесів (історіографрічний огляд)}

У статті розглядається історіографрія історико-культурних процесів, які відбуваються в африканському суспільстві на прикладі їх соціально-економічної і політичної трансформації крізь призму взаємозв'язків і взаємовпливів Заходу і Сходу. Політична конфронтація підриває основи діалогу культур. В ией період, коли тяжіють екстремістські гасла, розрив Африки і Заходу часом здається неподоланим, і він посилювався хаосом перших років їі незалежного розвитку. В історіографрічних дослідженнях значна увага приділяється питанням трансформації в соціокультурній $і$ економічній сфрерах в різних регіонах Афррики, проводиться їх порівняльний історикокультурний аналіз щодо рис схожості та невідповідності.

Також зазначається, що культура Заходу й Африки взаємодіють із сивої давнини. Проте, починаючи з епохи європейського Відродження, створюється і тривалий час розширюється стадіальний розрив в історичному розвитку Заходу та "незахідних" країн, що $є$ перешкодою ефективним культурним контактам. Як наслідок, трансформації в африканському суспільстві набувають конфліктного характеру.

Ключові слова: історіографрія, Африка, історико-культурна традиція, трансформація, цивілізація.

В сучасній історичній, культурологічній науці, яка займається історією народів Африканського континенту, можна виділити три основні тематичні блоки, згідно з якими точаться дискусії, скликаються міжнародні конференції, зокрема: 1) соціокультурні і цивілізаційні аспекти процесів суспільної інтеграції; 2) семіотичні моделі африканської культури і їх трансформації; 3) процеси та перспективи модернізації сучасних африканських суспільств.

В межах першого блоку можна виділити такі питання, як роль стародавніх культових центрів у процесах інтеграції та розвитку африканських суспільств, інтеграційне значення ісламської культури й ісламських інститутів (тарикатів), роль лінгвістичної політики африканських країн у процесах національної інтеграції і міжцивілізаційної 
взаємодії. Так, в дослідженнях Н. Кочакової (Африка. История, историография, (1980)) головна увага приділяється інтеграційним функціям Іле-Іфе - міста в Нігерії, яке $є$ стародавнім сакрально-культурним центром Західної Афррики. Існує думка, що це місто є історичною прабатьківщиною багатомільйонного народу йоруба. Дослідниця підкреслює, що протягом відомої нам історії Іле-Іфе виконує об'єднавчу роль народів йоруба як в колоніальний період - на значній території Західної Африки, так і в сучасний період - на території Нігерії і в межах йорубської діаспори в країнах Америки. При цьому Н. Кочакова особливо підкреслює, що інтегруюча роль Іле-Іфе визначається його сакральними функціями. В доколоніальний період Іле-Іфре - це джерело та еталон державності і культури: про це говорять міфри про походження правлячих династій йорубських держав, обряди, інсталяції, експорт релігійних обрядів, культурних навичок і т. ін. В сучасний період роль Іле-Іфе як Мекки не тільки для йоруба Нігерії, але і для нащадків рабів-йоруба в країнах Латинської Америки і США укріплюється як традиційними методами, так і зусиллями йорубських вчених. На сьогодні отримала розвиток нова міфотворчість на основі писемної культури, минуле інтерпретується відповідно до сучасних завдань. З'явилися і політичні мотиви, а саме проголошується світовий характер цивілізації Іфре.

Проблемам цивілізації Тропічної Африки та динаміки історичного процесу на континенті у доколоніальну епоху присвячені праці Д. Бондаренка (Историография и источниковедение истории стран Азии и Африки (1980)), в яких досліджуються цивілізаційні особливості Африки на південь від Сахари, які не тільки визначили наслідки контактів між Африкою і Європою задовго ще до появи біля африканського узбережжя перших каравел білої людини, але і сприяли тому, що протягом декількох століть континент залишається об'єктом експансії: колоніальної, економічної і, нарешті, військово-політичної. Специфріка полягає в тому, що європейський вплив, не говорячи про арабський, залишився зовнішнім фрактором еволюції Африки. Цивілізаційні властивості континенту збереглися такими, як і були за своєю суттю, незважаючи навіть на те, що вони більшою чи меншою мірою піддалися стимульованій європейцями трансформації. Таким чином, на думку дослідника, тропічно-африканську цивілізацію в цілому слід вважати архаїчною, переважно адаптаційною, а не еволюційною за типом розвитку. Подібної думки дотримується і С. Сенюткін (Африка сегодня: факты, события, суждения (1991)), вивчаючи історію Єгипту, який географрічно розташований на стику цивілізацій. Під впливом міжнародної ситуації та в ході внутрішнього соціально-економічного 
розвитку Єгипет у XIX ст. усе більше стає схожим на сполучний ланцюг між західною буржуазною і східною ісламською цивілізаціями. При цьому слід відмітити і негативні сторони цього процесу - країна фрактично перетворилася на колонію, переживаючи політичну нестабільність та часті зіткнення між окремими верствами еліти.

Досліджуючи соціально-інтегруючу роль тарікатів у Тропічній Африці, О. Саватєєв (Культура Африки в мировом цивилизационном процессе (1996)) відмічає спорідненість релігійно-магічної практики тарікатів з обрядовою стороною африканських традиційних релігій, що стало фрактором перетворення тарікатів не тільки на соціальноекономічні об'єднання, які згуртовані дисципліною, що базується на повазі і слухняності духовним наставникам, але і традиційною формою суспільної організації незалежно від національної та державної належності.

Протягом усього колоніального періоду в країнах Магрибу Алжирі, Тунісі і Марокко - офріційною мовою була фрранцузька мова. В. Комар (Современная Африка: итоги и перспективы развития (1993)), досліджуючи проблему арабізації і лінгвістичної політики в цих країнах, підкреслює, що після досягнення ними незалежності послідовно проводиться політика арабізації усіх сфер національного життя. Слід наголосити, що лінгвістичні проблеми як фактор інтеграційних процесів мають у кожній країні специфічні риси, які пов'язані із соціально-політичними й історичними обставинами. Особливо гостра та політизована мовна проблема в Алжирі. Проте, незважаючи на різне ставлення до статусу французької мови в країнах Магрибу, вона усе ще широко застосовується в адміністративній і економічній сфрерах, засобах масової інфрормації, друку. 3 усього цього можна зробити висновок, що в наш час французька мова сприймається в регіоні як засіб міжцивілізаційного спілкування і $є$ одним із засобів встановлення та розвитку контактів із зовнішнім світом.

На сьогодні значна увага приділяється дослідженню питань трансформацій на Півдні Африки, проводиться їх порівняльний історико-культурний аналіз щодо рис схожості та невідповідності. Так, О. Притворов (Л. Блохин, 1993), розглядаючи проблему еволюції національно-патріотичної еліти в Південній Африці, підкреслює, що, зберігаючи свою цілісність у межах єдиної держави (чи ПАР, чи Зімбабве), еліта в господарському житті не має достатнього досвіду: в економіці панують білі. Як наслідок - трансформації в суспільстві набувають конфрліктного характеру. Мова йде про прогресуючий "розподіл праці" у владі: носії "ідеї" всесвітнього центру - носії місцевих 
ідей. Типовим прикладом структури управління сучасної південноафриканської компанії є: 1) верхівка - обмежена кількість білих власників; 2) представницько-розпорядницький прошарок - численна кількість співласників; 3) далі знову вузький прошарок білих розпорядників і, нарешті; 4) ієрархія досить плавно за ранговими шарами спадає донизу (типу "лесотський колапак"). Така структура свідчить про фрормування з національної еліти стану, який не схильний до саморозвитку, але готового інтегруватися у світову економіку капіталістичного типу.

Щодо другого блоку проблем слід відзначити точки зору І. Нiкіфрорової, Н. Ляховської, Є. Ряузової, І. Блінова, Е. Львової, В. Усачової та ін. на проблему взаємодії культур Африки і Заходу у XX ст. в контексті соціально-економічної і політичної інтеграції (Развивающиеся страны в системе глобальных процессов современности (долгосрочные тенденции) (1990)).

Так, відмічаючи, що культури Заходу й Африки взаємодіють із сивої давнини І. Нікіфорова підкреслює: починаючи з епохи європейського Відродження, створюється і тривалий час розширюється стадіальний розрив в історичному розвитку Заходу та "незахідних" країн, що $€$ перешкодою ефективним культурним контактам. Дійсно, на кінець XIX ст., коли відбувається розподіл Афррики між європейськими державами, цей розрив та зумовлене ним взаємне нерозуміння європейців і африканців досягає максимуму, до того ж колонізатори вважають африканські народи такими, що не мають власної культури і, таким чином, розглядають своє проникнення в Африку як "цивілізаторську місію". Разом з тим вже на початку XX ст. в середовищі інтелігенції західних країн формується інше, більш адекватне сприйняття африканської культури й особливо негро-африканського традиційного мистецтва як самобутнього, продуктивного в культурному плані, здатного надати західному мистецтву (образотворчому, музичному) новий імпульс розвитку. У 20-30-ті pp. XX ст. в країнах Африки з'являється інтелігенція, яка була залучена до західної культури внаслідок впровадження в цих країнах європейської освітянської системи. Ії̈ сприйняття Заходу в цілому амбівалентне: віддаючи належне гуманістичним традиціям західної культури, африканці відмічають негативні сторони сучасної західної цивілізації: фетишизацію технічного прогресу, безцеремонний експансіонізм, расові забобони і т. ін. Ця критика стала особливо різкою після Другої світової війни, а саме в роки піднесення антиколоніального руху, який переріс у низці країн у збройну боротьбу. Політична конфронтація підриває основи діалогу культур. В цей період, коли тяжіють екстремістські гасла, розрив Африки і Заходу часом здається неподоланим, і він поглиблювався 
хаосом перших років ії незалежного розвитку. Але у 70-ті роки, й особливо у 80-90-ті рр. ситуація змінюється. Це знаходить відображення, зокрема, в художній літературі, яка інтенсивно розвивається, переважно європомовній, і яка саме в цей час досягає в багатьох країнах континенту духовної і художньої зрілості. Тепер африканці більш тверезо оцінюють як позитивні, так і негативні сторони західної цивілізації, намагаючись сказати власне слово з проблем світового співтовариства щодо місця в сучасному світі Африки і її культури, яка інтенсивно модернізується при використанні західного культурного досвіду, але в той же час і зберігає свою неповторність. 3 80-х рр. XX ст. у творчості фрранкомовних письменників, як зазначає Н. Ляховська, визначається поворот від апології аутентичних африканських соціальних інститутів та традиційних духовних цінностей до ідей примирення різних цивілізацій, культур і навіть релігій. Формується якась "компромісна тенденція, що пов'язана із змінами в особистісній свідомості африканців". Ця кристалізуюча гуманістична парадигма в африканських літературах кінця століття (визнання уселюдянного братерства та загально-світового значення духовних цінностей усіх народів) конкретно прослідковується в творчості романістів Конго (Браззавіль), таких, як Емманюель Донгала та Жан П'єр Макута Мбуку.

Слід зазначити, що португальська література - література колишньої метрополії - значно вплинула на фрормування низки португаломовних літератур в Латинській Америці, Африці й Азії. Є. Ряузова звертає увагу на те, що у міру свого розвитку ці "дочірні" літератури починають здійснювати усе більший вплив на португальську літературу. В наш час тісний зв'язок португальської літератури з літературами португаломовного світу допомагає Португалії подолати комплекс "малої нації", що вразив її суспільну свідомість після втрати заморських колоній. Як вважає видатний португальський романіст Фернандол Намора, тісні контакти з лузофонними літературами світу необхідні португальській літературі, оскільки це дає більш чітку уяву про те, чим ми самі $є$, зокрема й у світовому контексті.

Стійкість норм поведінки і мислення народів архаїчної культури отримує своє адекватне вираження в існуванні закономірної, логічної системи позначень. Міфологічна свідомість формується тут через особливу образотворчу мову із своїм певним словником. І. Блінов підкреслює, що саме через образотворчу діяльність узагальнюються окремі явища життя, вибудовуються причинно-спадкові зв'язки між ними. Здатність до узагальнення складається з конкретних спостережень (наприклад, тінь - умовний узагальнюючий силует, який несе інформацію про тримірність фігури). Для більшої інформативності 
зображення в ньому поєднуються усі важливі елементи об'єкта, які часто можна побачити лише з різних точок простору. Сюжет може повертатися у певній змістовій послідовності, принцип ритмічного повтору несе в собі потенційну енергію життєвого ритму. При цьому формоутворення, "колірне розуміння" невід'ємні від загальних світоглядних концепцій простору - часу. Властива архаїчній культурі віра у загальний взаємозв'язок явищ визначає ставлення до творчості як до магічного акту. Необхідно перш за все самому відчути красу речі, яку створюєш, тільки тоді вона зробить певний вплив і на інших. У сприйнятті африканського мистецтва європейськими художникамиавангардистами акцент робиться на "простоті" як самопереважаючої цінності. Художників приваблювала перш за все можливість відтворювати об'єм на площині без застосування засобів світлотіні - оволодівши цим методом, можна отримати творчі результати без багаторічної академічної підготовки. В той час, коли в Африці міфологія $€$ ґрунтом національного мистецтва, в Західній Європі, де традиція народного мистецтва втрачена, неоміфологія масової культури дозволяє ії споживачу подолати соціальні і культурні бар'єри, не виходячи, проте, за жорсткі межі універсальної моделі відносин. Найважливіша особливість знаково-символічної моделі сучасної західної культури полягає в тому, що вона формує зовнішньо зорієнтовану особистість, для якої головне не свій духовний світ, а психологія відносин з суспільством, як зазначає І. Блінов. Один із провідних напрямків у сучасному західному дизайні - це "стайлінг": зміна зовнішньої форми, часто просто оболонки витвору, без перебудови внутрішньої конструкції. I як наслідок, середовище перебування в розвинутих країнах усе більше втрачає співрозмірність людині. Спроби протидіяти цьому частіше за усе полягають в механічному монтажі елементів, які взяті з історії, що інколи приводить до окарикатурювання традиційних фрорм. 3 цього можна зробити висновок, що Африка, де збереглися майже усі відомі історії види суспільного ладу, має великий творчий потенціал, у той час як довготривала індустріалізація на Заході зробила незворотнім процес зникнення у творчості дійсно національного, своєрідного.

Розширене трактування тенденції в антропоніміці африканських народів простежує Е. Львова, яка зазначає, що сучасний етап культурного розвитку народів Африки засвідчує, що одним з важливих питань процесу взаємодії культур є питання про роль і місце традиції та традиційності. Існують дві точки зору на цю проблему: одна, що в традиції закладено майбутнє ядро інтеграції чи на локальному, чи на загальнодержавному рівні, друга - традиція $є$ гальмом сучасного 
розвитку Африки на шляху ії інтеграції у світове товариство. Слід зазначити, що повсюдне звернення до традицій, це намагання не тільки зберети існуюче, але і відтворити те, що втрачене, Проте це є, на її думку, "начебто традиційність" чи "псевдотрадиційність", що можна простежити в різних сферах розвитку африканського суспільства: в соціально-економічній - "уджамая" в Танзанії чи "фукулюн" на Мадагаскарі; в духовній - створення нових міфів у йоруба в Нігерії чи створення "традиційної" релігії у кафффічо в Ефіопії; в правовій спекулятивне використання норм звичайного права у сіюхвилиних інтересах, наприклад, в Кенії, і т. ін. Аналогічні тенденції спостерігаються і в сучасній антропоніміці африканських народів: при намаганні зберегти чи відродити традиційні імена (Того, Заїр та ін.) з'являється нова система імен, яка не повторює канонічні імена доколоніального часу. Е. Львова вважає, що подібні явища демонструють зникнення в Африці суто етнічних традиційних елементів і виникнення нових загальноафриканських традицій.

Прикладом трансформації може слугувати звернення до аналізу трансформації образів політичних партій ПАР в ході історичної виборчої кампанії 1994 р., яка продемонструвала намагання більшості населення не тільки до радикальних змін політичної ситуації в країні, але і в громадянському світі можна переконатися, що внаслідок виборів більше голосів набрали ті партії і рухи, які пішли на компроміси, які відмовилися від деяких постулатів і тим самим забезпечили сам фракт проведення виборів. В. Усачова, аналізуючи передвиборні кампанії таких партій, як Національна партія, Африканський національний конгрес, Партія Свободи Інката, Демократична партія та Пан-Африканський Конгрес, робить висновок: по-перше, трибалізм, властивий багатьом країнам Африки, не визначає політичного життя ПАР, по-друге, перемогли партії, які мали прихильників як на території усієї країни, так і в усіх соціальних верствах і групах, а також ті, що намагалися подолати расові стереотипи.

Що стосується третього блоку, то слід вказати, що цивілізаційні та соціокультурні особливості модернізації африканських спільнот на шляху їх інтеграції у світове співтовариство при усій значущості соціально-економічних аспектів інтеграційних процесів не можуть виступати як самостійний фактор, бо інтереси і мотивація, технологія і механізми, що визначають інтеграційні рішення, мають явно виражене соціокультурне підґрунтя. Так, О. Ткаченко (Развивающиеся страны в системе глобальних процессов современности долгосрочные тенденции (1990)) зазначає, що незважаючи на те, що Схід продемонстрував здатність продуктивно "переробляти" хвилі модернізації 
(вестернізації), що кордони між центрами та периферією світового господарства стають усе більше примарними чи зникають зовсім, незважаючи на впровадження елементів політичної демократії, мотиви і передумови модернізації східних суспільств, її кінцева мета і наслідки чітко не визначені. В процесі трансформації східних суспільств пріоритет належить економічним методам, а саме програмам підтримки дрібного і середнього підприємництва. Проте соціокультурна компонента національних еліт заважає цьому процесу.

Програми структурної трансформації економіки, які були запропоновані МВФ різним країнам, зокрема африканським, на думку $€$. Морозенської (В. И. Гусаров, (2008)), складають основу для інверсійної реакції традиційної частини їх господарського середовища. Ця реакція в різних країнах неоднакова і залежить від співвідношення модернізованих і традиційних господарських структур та ступеня їх впливу на економічний розвиток (в кількісному і якісному виразі). Проте у всіх африканських країнах спостерігається властивий інверсійним процесам ефект - поряд із осучасненням традиційних господарських структур відбуваються зміни традиціоналізму в організації і функціонуванні економіки, перенесення центру ваги у розвитку на активізацію традиційного дрібного підприємництва.

Відомо, що соціально-економічне становище в суспільстві та стан його інтелектуального простору, характер психологічних і ціннісних установок, рівень його освіченості, інформованості і освіченості речі взаємопов'язані. Вплив західної культури став невід'ємною рисою еволюції в африканських суспільствах, у той час як стан інтелектуального простору в Африці усе ще визначається традиційними установками, тобто наявністю універсальних для усіх членів суспільства сакральних цінностей, головною з яких $є$ "репродукування і збереження існуючої системи". В умовах переваги традиційного типу свідомості, на думку І. Катагощиної (Культура Африки в мировом цивилизационном процессе (1996)), які розроблені міжнародними організаціями за західним зразком моделі розвитку для Африки, включаючи стратегію структурної перебудови економіки, позитивних наслідків не дає. Проте це не означає, що в Африці в принципі неможливі ніякі соціально-економічні перетворення. Тут вже давно в процесі взаємодії культур почалась модернізація усіх сфрер діяльності і буття, підриваючи одні форми традиційної культури, стимулюючи їх перехід в інші нетрадиційні (інститут патерналізму, клієнтелізму і т. ін.). Украй складною залишається проблема "інтелігенція і маси". Адаптація населення до сучасних умов вимагає засобів, яких немає чи недостатньо, особливо коли Захід втрачає інтерес до Африки. Тим 
не менш суспільна трансформація континенту неминуча: світове співтовариство намагається внести свою частку в розвиток інтелектуального простору африканських країн. Приклад - проєкт ЮНЕСКО "Розвиток людини", який покликаний сприяти покращенню показників розвитку людського потенціалу.

На Африканському континенті, незважаючи на серйозну економічну кризу, спостерігається новий виток розвитку інтеграційних процесів усіх рівнів, варіанти інтеграції країн Африки, що розвиваються (південніше Сахари і Північної Африки), у світове господарство. Для успіху процесів, на думку Г. Смірнова, необхідно враховувати декілька моментів: 1) Африка - традиційний експортер мінеральної сировини та сільськогосподарської продукції; 2) виявляти нові ніши участі в міжнародному розподілі праці; 3) використовувати переваги, що склалися і які виходять із різниці національної та "світової" вартості факторів виробництва й інших ресурсів; 4) аналізувати загальні для країн з перехідною економікою проблеми подолання відставання в рівнях економічного та соціального розвитку; 5) найбільшу увагу слід приділити співвідношенню ролі держави та ринкових механізмів при подальшій трансформації африканських економічних систем. В. Гусаров, продовжуючи думку Г. Смирнова, підкреслює, що інтеграція на континенті відбувається головним чином "в ширину", а не "в глибину": в умовах існування відсталих соціально-економічних та техніко-економічних структур потенціальними соціальними носіями інтеграції є представники "верхніх поверхів виробництва", у той час як переважаючий традиційний сектор економіки не створює бази для поглиблення інтеграційних процесів (Гусаров В. И. (2008)). До комплексу фракторів, які перешкоджають інтеграції в Африці, відноситься також "балканізованість" Африки, неврегульованість етноконфесійних та прикордонних проблем і відповідно міждержавні протиріччя і конфрлікти, внутрішньополітична нестабільність в багатьох країнах, масова неграмотність, культурно-мовна веселка і т. ін.

Слід звернути увагу на значну неоднорідність Африканського континенту в цивілізаційному плані, а саме специфіку кочових та осілих цивілізацій, особливості релігійних, конфесійних соціумів, історикоетнічні компоненти африканських народів, надзвичайно заперечливі стереотипи національних еліт, різні економіко-географічні центри тяжіння і т. ін., а також несприятливе становище у всіх сферах життя африканського суспільства. Л. Янчишина (Развивающиеся страны в системе глобальных процессов современности (долгосрочные тенденции) (1990)) підкреслює, що кінець біполярного світу поглибив кризову ситуацію. На тлі відходу від багатоваріантного соціально- 
економічного розвитку та послаблення ролі континенту для економіки постіндустріального суспільства відбувається витіснення африканських країн із світового капіталістичного ринку, бо інтеграція світового господарства в одноподібну самовідновлюючу систему формує такий ринок (регулятор системи світового господарства), при якому національні ринки гублять самостійність і, що найважливіше, втрачають можливість впливати на регулювання міжгалузевих пропорцій відтворення. Аналіз ситуації, яка склалася, показує, що зараз світову економіку неможливо розглядати як суму національних господарств, пов'язаних одне з одним засобом зовнішньої торгівлі: сучасний світовий ринок вже став інструментом економічного тиску на країни. Разом з тим жорсткі процеси формування єдино подібного і взаємозалежного світу призвели до того, що економічна слабка розвинутість втратила національну і релігійну обмеженість і перетворилась на загальнолюдську проблему: небезпеку розростання соціальноекономічної стагнації в найменш розвинутих країнах, а в Африці зосереджено більшість бідних держав світу, і це не тільки ставить на межу господарської катастрофри, яка веде до серйозних соціальних потрясінь, але і створює реальну основу міжнародної економічної і політичної нестабільності. Сьогодні не можна не враховувати своєрідність цивілізаційного середовища, зокрема африканського, в якому відбувається формування регіональних підходів до глобальних проблем, тим паче, що ці проблеми торкаються усіх сфер життєдіяльності суспільства: політичної системи, економіки, соціальної структури, культури і т. ін.

Цивілізаційний аспект екології в країнах з різним рівнем соціальноекономічного розвитку, процеси, які відбуваються в світі, передбачають розвиток на планеті "іншого цивілізаційного простору", як зазначає О. Мальцев (Л. Блохин, (1993)), який донедавна називався "третій світ", - простору, що $є$ конгломератом різних "традиційних, але вже модернізованих культур".

Виходячи з вищезазначених проблем, можна зробити такий висновок, що на сьогодні в планетарній цивілізації - це можна бачити і на прикладі африканської цивілізації - склалась ситуація, коли культура будь-якого соціуму здатна виконувати свою історичну місію на шляху від внутрішньоетнічної консолідації до міжетнічної інтеграції і далі. Це можливо вже тому, що з самого початку в кожній цивілізаційній традиції закладені ті загальнолюдські цінності, які наполегливо шукають еліти усіх суспільств, але так і не знаходять їх у ссрері своїх політичних, етнічних чи професійних зазіхань і чомусь не хочуть їх бачити в духовній спадщині своїх народів. 


\section{Література}

1. Африка. История, историография: сб. ст. / АН СССР, Ин-т Африки. Москва: Наука, 1980. 240 с.

2. Африка сегодня: фракты, события, суждения / АН СССР. ИН-т Афррики. Москва: Наука, 1991. Вып. 1. 28 с.

3. Блохин Л. Африка: культура - экономика - экология: научно-аналит. обзор. Москва, 1993. 47 с.

4. Гусаров В. И. Северная Африка: полвека независимого развития (социально-экономические аспекты). Москва: Институт Африки РАН, 2008. $308 \mathrm{c}$.

5. Историография и источниковедение истории стран Азии и Африки: сб. ст. Ленинград: Изд-во ЛГУ, 1980. 131 с.

6. Культура Афррики в мировом цивилизационном процессе. Москва: Восточная лит-ра РАН, 1996. 335 с.

7. Развивающая страны в системе глобальных процессов современности (долгосрочные тенденции): мат. "круг. ст." / АН СССР, Ин-т Афрр.; отв. ред. Б. Б. Рунов. Москва, 1990. 144 с.

8. Современная Афррика: итоги и перспективы развития. Москва: Наука, 1993. 348 с.

\section{References}

1. Afrika. Istoriya, istoriografiya: Sb. st. (1980) / AN SSSR, In-t Afriki. [Africa. History, historiography: Sat. Art.] USSR Academy of Sciences, Inst. Of Africa. Moskva: Nauka. [in Russian].

2. Afrika segodnya: fakty, sobytiya, suzhdeniya. (1991) [Africa today: facts, events, judgments / AN SSSR. In-t Afriki. Moskva: Nauka. Vyp. 1. [in Russian].

3. Blohin, L. (1993) Afrika: kultura-ekonomika-ekologiya: Nauchno-analit. obzor [Africa: culture - economy - ecology: Scientific-analytical. review]. Moskva. [in Russian].

4. Gusarov V. I. (2008) Severnaya Afrika: polveka nezavisimogo razvitiya (socialno-ekonomicheskie aspekty). [North Africa: half a century of independent development (socio-economic aspects). Moskva: Izd-vo Institut Afriki RAN. [in Russian].

5. Istoriografiya i istochnikovedenie istorii stran Azii i Afriki: [Historiography and source study of the history of Asia and AfricaSb. st. (1980) L.: Izd-vo LGU. [in Russian]

6. Kultura Afriki v mirovom civilizacionnom processe (1996). [The culture of Africa in the world civilization process.] Moskva: "Vostochnaya lit-ra" RAN. [in Russian]

7. Razvivayushaya strany $v$ sisteme globalnyh processov sovremennosti (dolgosrochnye tendencii) [Developing countries in the system of global processes of modernity (long-term trends): Mat. "circle. st.] Mat. "krug. st. ". (1990) / AN SSSR In-t Afr. Otv. red. B. B. Runov. M. [in Russian]

8. Sovremennaya Afrika: itogi i perspektivy razvitiya [Modern Africa: results and prospects of development] (1993) Moskva: Nauka [in Russian]. 


\section{E. Kuchmenko}

Doctor of Historical Sciences, Professor, Department of World History and International Relationships, Nizhyn Mykola Gogol State University

Transformations of african society in the context of interaction of historical and cultural processes (historiographical review)

The article examines the historiography of historical and cultural processes taking place in African society on the example of their socio-economic and political transformation through the prism of the interrelationships and interactions of West and East. Political confrontation undermines the foundations of intercultural dialogue. During this period of extremist slogans, the rift between Africa and the West sometimes seems insurmountable, and it is exacerbated by the chaos of the first years of its independent development. In historiographical research, considerable attention is paid to issues of transformation in the socio-cultural and economic spheres in different regions of Africa, their comparative historical and cultural analysis of similarities and inconsistencies.

It is also noted that the culture of the West and Africa have interacted since ancient times. However, since the European Renaissance, a gradual gap in the historical development of the West and "non-Western" countries has been created and widened for a long time, which is an obstacle to effective cultural contacts. As a result, transformations in African society are becoming conflictual.

Key words: historiography, Africa, historical and cultural tradition, transformation, civilization. 